\title{
Randomized placebo-controlled trial comparing fluticasone aqueous nasal spray in mono-therapy, fluticasone plus cetirizine, fluticasone plus montelukast and cetirizine plus montelukast for seasonal allergic rhinitis
}

\author{
G. Di Lorenzo*, M. L. Pacor†, M. E. Pellitteri*, G. Morici*, A. Di Gregoli*, C. Lo Bianco*, V. Ditta*, \\ N. Martinelli†, G. Candore $\ddagger$, P. Mansueto*, G. B. Rini*, R. Corrocher $\dagger$ and C. Caruso $\ddagger$ \\ *Dipartimento di Medicina Clinica e delle Patologie Emergenti, Università di Palermo, Italy, $\dagger$ Dipartimento di Medicina Clinica e Medicina Sperimentale, \\ Università di Verona, Italy and $\ddagger$ Dipartimento di Biopatologia e Metodologie Biomediche, Università di Palermo, Italy
}

\begin{abstract}
Summary
Background Corticosteroids are considered to be particularly effective in reducing nasal congestion and are therefore recommended as first-line treatment in allergic rhinitis patients with moderate to severe and/or persistent symptoms.

Objective We compared the clinical efficacy of fluticasone propionate aqueous nasal spray (FPANS) $200 \mu \mathrm{g}$ given once daily, administered in mono-therapy or combined therapy with a $\mathrm{H}_{1}$ receptor antagonist (cetirizine, CTZ) or with a leukotriene antagonist (montelukast, MSK), and the combined therapy of CTZ plus MSK in the treatment of patients affected by allergic rhinitis to Parietaria during natural pollen exposure. In addition, we examined the effect of the treatment on eosinophil counts and eosinophil cationic protein (ECP) in nasal lavage performed at beginning of season, during season and at the end of the season.

Methods One hundred patients aged 12-50 years (mean \pm SD $31.8 \pm 9.6$ ) with a history of moderate to severe Parietaria pollen-induced seasonal allergic rhinitis were selected. A randomized, double-blind, double dummy, placebo (PLA)-controlled, parallel-group study design was used. Patients were treated FPANS $200 \mu \mathrm{g}$ once daily $(n=20)$ or with FPANS $200 \mu \mathrm{g}$ once daily, plus CTZ $(10 \mathrm{mg})$ in the morning $(n=20)$, or with FPANS $200 \mu \mathrm{g}$ once daily, plus MSK $(10 \mathrm{mg})$ in the evening $(n=20)$ or with CTZ $(10 \mathrm{mg})$ in the morning plus MSK in the evening $(n=20)$ or matched PLA $(n=20)$. Assessment of efficacy was based on scores of daily nasal symptoms and on eosinophil counts and ECP in nasal lavage.

Results All treatments showed significant differences $(P<0.001)$ compared with PLA in terms of total symptom, rhinorrhea, sneezing and nasal itching scores. Concerning nasal congestion on waking and daily only the groups treated with FPANS in mono-therapy or in combined therapy showed significant differences compared with PLA. Comparing the group treated with FPANS alone and the groups treated with FPANS plus CTZ, we found significant differences for total symptom score $(P=0.04)$ and for nasal itching $(P=0.003)$. The comparison between FPANS plus CTZ and FPANS plus MSK showed significant difference for nasal itching $(P=0.003)$. Finally, there were significant differences between the group treated with FPANS and the group treated with CTZ plus MSK for total symptom score $(P=0.009)$, for nasal congestion on waking $(P<0.001)$ and nasal congestion daily $(P<0.001)$. Also the comparisons between the group treated with FPANS plus CTZ and the group treated with CTZ plus MSK demonstrated significant differences $(P<0.001)$ for total symptom, for nasal congestion on waking and for nasal congestion on daily, for rhinorrhea $(P=0.04)$ and for nasal itching $(P=0.003)$ scores. Concerning the comparison between the group treated with FPANS plus MSK and the group treated with CTZ plus MSK we found significant differences for total symptom score $(P=0.005)$, for nasal congestion on waking $(P<0.001)$ and for nasal congestion on daily $(P<0.001)$. No other differences were observed between the groups. Concerning blood eosinophil counts, significant differences were found between the treatments with FPANS in mono-therapy or in combined therapy with PLA group during and at the end of the season $(P=0.0003$ and $P<0.0001$, respectively). Concerning eosinophils and ECP in nasal lavage, all treatments showed significant differences $(P<0.001)$ compared with PLA. Besides, there were significant differences $(P<0.001)$ between the groups treated with FPANS alone or in combined therapy and the group treated with CTZ plus MSK.
\end{abstract}

Correpondence: Dr Gabriele Di Lorenzo, Dipartimento di Medicina Clinica e delle Patologie Emergenti, Via del Vespro 141, 90127 Palermo, Italy. E-mail: dilo601@unipa.it 
Conclusion The results of this comparative study demonstrate that FPANS is highly effective for treating patients affected by allergic rhinitis, with efficacy exceeding that of CTZ plus MSK in combined therapy. In addition, the regular combined therapy of FPANS plus CTZ or plus MSK would not seem to offer substantial advantage with respect to FPANS in mono-therapy in patients affected by seasonal allergic rhinitis.

Keywords cetirizine, eosinophil cationic protein, eosinophils, fluticasone propionate, montelukast, nasal lavage, Parietaria, pollen season

Submitted 31 March 2003; revised 16 June 2003; accepted 17 October 2003

\section{Introduction}

The current guidelines from the European Academy of Allergy and Clinical Immunology (EAACI) working party on the management of rhinitis and the Allergic Rhinitis and its Impact on Asthma (ARIA) initiative state that antihistamines are first-line therapy for allergic rhinitis [1, 2]. However, these guidelines also point out that antihistamines, although effective at reducing rhinorrhea, sneezing, itching and eye symptoms, are relatively ineffective at reducing nasal blockage $[1,2]$. However, corticosteroids are considered to be particularly effective in reducing nasal congestion and are therefore recommended as first-line treatment in allergic rhinitis patients with moderate to severe and/or persistent symptoms $[1,2]$. Furthermore, a meta-analysis performed in 1998 , looking at the effect of a number of first- and secondgeneration antihistamines vs. intranasal corticosteroids on nasal blockage, showed that steroids performed better in every study analysed, with an overall significant difference in the meta-analysis [3].

A recent development in the treatment of asthma has been the introduction of leukotriene receptor antagonists (montelukast (MSK), zafirlukast and pranlukast). They are superior to placebo (PLA) in improving the symptoms of asthma but are generally not as effective as steroids and their place in the management of asthma is still controversial [4-6].

A number of studies have shown that the combination of antihistamines and antileukotrienes in allergic rhinitis has shown additional efficacy over single treatment [7-9]. Other studies have also shown combination therapy to be as effective as certain intranasal corticosteroids [8]. A further study, looking at the combination of MSK and cetirizine (CTZ) against the intranasal corticosteroid budesonide, also showed a significant reduction in all allergic rhinitis symptoms, with no difference between the treatment groups [9].

No study has compared topical corticosteroids in monotherapy or in combined therapy with mediator antagonist in patients affected by allergic rhinitis.

In this study, we compared the clinical efficacy of fluticasone propionate aqueous nasal spray (FPANS) $200 \mu \mathrm{g}$ given once daily, administered in mono-therapy or combined therapy with a $\mathrm{H}_{1}$ receptor antagonist (CTZ) or with a leukotriene antagonist (MSK), and the combined therapy of CTZ plus MSK in the treatment of patients affected by allergic rhinitis to Parietaria during natural pollen exposure. In addition, we examined the effect of the treatments on eosinophil counts and eosinophil cationic protein (ECP) in nasal lavage performed at beginning of season, during season and at the end of the season.

\section{Materials and methods}

\section{Population}

One hundred patients aged $12-50$ years (mean \pm SD $31.8 \pm 9.6$ ) with a history of moderate to severe Parietaria pollen-induced seasonal allergic rhinitis were selected, by chart review, from outpatients of Departments of Medicina Clinica e Patologie Emergenti of University of Palermo and Medicina Clinica e Sperimentale of University of Verona (Italy). Patients were recruited based on a clinical history of allergic rhinitis, of the presence of positive skin prick test response to Parietaria pollen and finally of at least 2 years duration symptoms during Parietaria season. Patients were excluded if they had taken the following drugs: long-acting histamine antagonists within the past 6 weeks; inhaled, intranasal, or systemic corticosteroids or inhaled sodium cromoglycate within the past 4 weeks. Other exclusion criteria were the presence of concurrent infection of the paranasal sinuses, and/or of the upper or lower respiratory tract, and/or asthma, nasal surgery within the past year, structural nasal abnormalities or concurrent diseases that could interfere with the validity of the study results. Patients were also excluded if they were pregnant or lactating.

Before the study began, approval was obtained from the Ethic Committees of the two centres involved. Written informed consent was obtained from all enrolled patients.

\section{Study design}

A randomized, double-blind, double dummy, PLA-controlled, parallel-group study design was used. Patients, in each centre, received the following treatments:

1. FPANS, $200 \mu \mathrm{g}$ - aqueous nasal spray - fluticasone propionate $50 \mu \mathrm{g} /$ actuation, two actuations into each nostril in the morning plus PLA of CTZ in the morning and plus PLA of MSK in the evening.

2. FPANS, $200 \mu \mathrm{g}$ - aqueous nasal spray - fluticasone propionate $50 \mu \mathrm{g} /$ actuation, two actuations into each nostril in the morning plus CTZ $10 \mathrm{mg}$ in the morning and plus PLA of MSK in the evening.

3. FPANS, $200 \mu \mathrm{g}$ - aqueous nasal spray - fluticasone propionate $50 \mu \mathrm{g} /$ actuation, two actuations into each nostril in the morning plus MSK $10 \mathrm{mg} 1$ day in the evening plus PLA of CTZ in the morning.

4. CTZ $10 \mathrm{mg} 1$ day in the morning plus MSK $10 \mathrm{mg}$ in the evening plus PLA of fluticasone propionate nasal spray.

5. PLA of fluticasone propionate plus PLA of CTZ plus PLA of MSK. 
The pharmacist of University Hospital of Verona has prepared a specific set with the treatments in study. The investigators and patients were blinded to the contents of the sets. The pharmacist using commercially tablets of CTZ $\left(\right.$ Zirtec $^{\mathbb{R}}$, UCB, Italy) or tablets of MSK (Singulair ${ }^{\circledR}$, Merk Sharp and Dome, Italy) or fluticasone propionate nasal aqueous spray (Flixonase $^{\mathbb{R}}$ GlaxoSmithKline, Italy) or tablets of PLA or PLA of fluticasone propionate nasal aqueous spray prepared the sets. As regards the PLA of fluticasone propionate nasal aqueous spray, the pharmacist using empty bottle of fluticasone propionate prepared PLA of nasal spray using saline solution.

The treatment period started just before the beginning of the pollen season, without any run-in. Patients were treated for 6 weeks.

Each patient attended the clinics on four different occasions. This included an initial clinical visit, a second visit after 3 weeks of treatment and a final visit after 6 weeks of treatment (i.e. visit 3 ) and 2 weeks after the end of the treatment period (follow-up, visit 4).

At visit 1 symptom scores of rhinitis were assessed by patients by means of a visual analogical scale (0-12), and nasal lavage was performed. Enrolled patients received a daily record diary for nasal and eye symptoms. The study was conducted during the Spring 2001. Two centres documented local daily pollen counts throughout the study period.

The patients (10 patients for each treatment) enrolled in Palermo started the treatments at first week of April, whereas the patients (10 patients for each treatment) enrolled in Verona started the treatments at last week of April.

\section{Assessment of symptoms}

Patients were instructed to record their daily symptoms on diary cards. Nasal symptoms included nasal blockage on waking and during the day, rhinorrhea, sneezing and itching. Eye symptoms included watering and/or irritation. Nasal congestion was scored as follows: (0) not present; (1) slightly difficult breathing through the nose; (2) moderately difficult breathing through the nose; (3) very difficult or impossible breathing through the nose. Any other recorded symptom was scored as follows: (0) none; (1) mild (occasionally present); (2) moderate (rather frequent); (3) severe (persistent). Rescue medications included levocabastine nasal spray (50 $\mu \mathrm{g}$ per puff) and sodium cromoglycate eye-drops (4\% $\mathrm{w} / \mathrm{v})$. No other medication for rhinitis was permitted during the trial.

\section{Eosinophil blood counts}

A venous blood sample was collected and the eosinophils were counted in a Fuchs Rosenthal chamber after staining with eosinophil staining solution and results were expressed as eosinophils $\times 10^{-3} \mu \mathrm{L}[10,11]$.

\section{Nasal cytology}

Nasal lavage was performed using a disposable metered-dose nasal inhaler (Markos, Monza, Italy) filled with sterile, room temperature, normal saline solution. The device consisted of a plastic cup with two rooms. The central compartment was filled with sterile saline solution with a syringe; the external compartment collected the liquid after washing. Total input of saline solution was approximately $8 \mathrm{~mL}(4 \mathrm{~mL}$ in each nostril for $5 \mathrm{~min}$ ). To collect the nasal washings, the subjects were instructed to actively breathe during a Valsalva manoeuvre to harvest nasal fluid in the cup. Obtained samples were stored on ice and centrifuged at $400 \mathrm{~g}$ for $10 \mathrm{~min}$ at $4{ }^{\circ} \mathrm{C}$ and supernatant aliquots were stored at $-80^{\circ} \mathrm{C}$. The individual variation in the recovered vs. introduced volume was $86 \% \pm 8 \%$. Nasal eosinophil counts were performed on nasal lavage. One cytospin slide for each sample $\left(1 \times 10^{4}\right.$ cells in $170 \mu \mathrm{L}$ for slide $)$ was centrifuged at $10 \times \boldsymbol{g}$ for $10 \mathrm{~min}$ in a Shandon cytocentrifuge (Shandon Southern Ltd, Runcorn, Cheshire, UK). Slides were immediately fixed in $95 \%$ ethyl alcohol and dipped in WrightGiemsa stain. The slides were examined under oil immersion by light microscopy at magnification of $\times 400$. Eosinophil counts were expressed as percentage of 300 cells counted. All specimens were examined by the same microscopist $[12,13]$.

\section{ECP nasal fluid}

The assay of nasal ECP was performed with a Fluorescent Enzyme Immunoassay (FEIA) using the Pharmacia CAP ${ }^{\mathrm{TM}}$ system (Pharmacia, Uppsala, Sweden). The detection limit was $2 \mathrm{ng} / \mathrm{mL}$, and the interassay variation was less of $5.9 \%$ $[12,13]$.

\section{Pollen count}

Pollen was collected and measured daily throughout the study period. Pollen amounts were expressed as median of grain per cubic metre. Parietaria pollen recorded during the period study is shown in Fig. 1.

\section{Statistical analysis}

The primary assessment of efficacy was based on the differences between each treatment group vs. PLA for total symptom score and for every symptom of the rhinitis. Data are presented as mean ( $95 \%$ confidence interval, CI) of the mean of individual score. ANCOVA was used to account for any influence on treatment response of changes in pollen level over time. Adjusted values were subsequently averaged by



Fig. 1. Median of daily pollens counts for Parietaria during Spring 2001 in Sicily and Veneto, at site where the study was conducted. 
patient over the entire observation period. Averages by patient were examined using a 'mixed-effects' ANOvA model with, as main factors, the treatments (as fixed effect) and the centres (as random effect); $F$-values were calculated using the mean-squares of the interaction 'centres $\times$ treatments' as the error term. Differences between means were performed by Bonferoni's multiple range test (set at 95\% CI). Power analysis on post hoc comparisons was performed by the 'GPower' software package [14]. Comparisons are only denoted as being significant $(P<0.05$, two-tailed $)$ or not significant if our sample size exceeded the minimum sample size resulting from power analysis at $\beta=0.80$.

Blood eosinophil counts were expressed as mean $\pm \mathrm{SD}$. The nasal eosinophils and ECP were presented as mean $(95 \% \mathrm{CI})$ of the nasal eosinophils and nasal ECP at the end of the season minus nasal eosinophils and nasal ECP before the season. Differences between means were performed by Bonferoni's multiple range test (set at 95\% CI). All other analyses were performed using SYSTAT 10 software package.

\section{Results}

One hundred patients were randomized to treatments, 20 patients for each treatment (see above). For each group 10 patients were enrolled in Palermo and 10 in Verona. All patients began the treatment at the same week (see Study design) and all patients concluded the whole study, including the follow-up period. The baseline characteristics, with respect to duration of seasonal rhinitis, age of patients and mean blood eosinophil count are shown in Table 1.

\section{Assessment of efficacy}

Figures $2 \mathrm{a}-\mathrm{f}$ and Table 2 show total symptom, nasal congestion on waking and daily, rhinorrhea, sneezing and nasal itching scores, respectively. Data are reported as mean $(95 \% \mathrm{CI})$ of the mean of individual score during the treatment period. Table 2 shows the mean difference $(95 \%$ CI for difference) between the treatments.

All treatments showed significant differences $(P<0.001)$ compared with PLA in terms of total symptom, rhinorrhea, sneezing and nasal itching scores. Concerning nasal congestion on waking and daily only the groups treated with FPANS in mono-therapy or in combined therapy showed significant differences compared with PLA. Besides, there was no significant difference between CTZ plus MSK vs. PLA, concerning both nasal congestion on waking and daily.

Comparing the groups treated with FPANS alone and the groups treated with FPANS plus CTZ, we found significant differences for total symptom score $(P=0.04)$ and for nasal itching $(P=0.003)$. The comparison between FPANS plus $\mathrm{CTZ}$ and FPANS plus MSK showed significant difference for nasal itching $(P=0.003)$.

Finally, there were significant differences between the group treated with FPANS and the group treated with CTZ plus MSK for total symptom score $(P=0.009)$, for nasal congestion on waking $(P<0.001)$ and nasal congestion daily $(P<0.001)$. Also the comparisons between the group treated with FPANS plus CTZ and the group treated with CTZ plus MSK demonstrated significant differences $(P<0.001)$ for total symptom, for nasal congestion on waking and for nasal congestion on daily, for rhinorrhea $(P=0.04)$ and for nasal itching $(P=0.003)$ scores. Concerning the comparison between the group treated with FPANS plus MSK and the group treated with CTZ plus MSK we found significant differences for total symptom score $(P=0.005)$, for nasal congestion on waking $(P<0.001)$ and for nasal congestion on daily $(P<0.001)$. No other differences were observed between the groups.

The median percentage of days without eye symptoms in the five treatments was not statistically different (FPANS group 60.2 days; FPANS plus CTZ group 72.1days; FPANS plus MSK group 70.5 days; CTZ plus MSK group 73.4 days; PLA group 58.4 days). Finally, the use of rescue medication, expressed as the median of days without the use of levocabastine nasal spray, was significantly lower in the groups treated with FPANS in mono-therapy (96.4 days) or in combined therapy FPANS plus CTZ group (97.0 days) and FPANS plus CTZ group (95.7 days) than either the CTZ plus MSK group (92.7, $P=0.03)$ or PLA group $(68.1, P<0.001)$.

\section{Blood eosinophil counts}

No significant differences were found in the blood eosinophil counts between the groups in the samples taken before the beginning of season (Table 3). Significant differences were found between the treatments with FPANS in mono-therapy or in combined therapy with PLA group during and at the end of the season $(P=0.0003$ and $P<0.0001$, respectively).

Table 1. Baseline characteristics

\begin{tabular}{|c|c|c|c|c|c|}
\hline & $\begin{array}{l}\text { FPANS group } \\
(n=20)\end{array}$ & $\begin{array}{l}\text { FPANS plus CTZ group } \\
(n=20)\end{array}$ & $\begin{array}{l}\text { FPANS plus MSK group } \\
(n=20)\end{array}$ & $\begin{array}{l}\text { CTZ plus MSK group } \\
(n=20)\end{array}$ & $\begin{array}{l}\text { PLA group } \\
(n=20)\end{array}$ \\
\hline Male/female ratio & $12 / 8$ & $8 / 12$ & $6 / 14$ & $9 / 11$ & $6 / 14$ \\
\hline Mean age (years) & 30.5 & 32.8 & 27.1 & 34.3 & 34.2 \\
\hline Age range (years) & $15-50$ & $14-48$ & $12-48$ & $20-44$ & $14-37$ \\
\hline \multicolumn{6}{|l|}{ Duration of rhinitis } \\
\hline $2-4$ years & 11 & 11 & 11 & 12 & 10 \\
\hline $5-9$ years & 05 & 06 & 06 & 05 & 04 \\
\hline$\geqslant 10$ years & 04 & 03 & 03 & 03 & 06 \\
\hline
\end{tabular}

FPANS, fluticasone propionate aqueous nasal spray; CTZ, cetirizine; MSK, montelukast; PLA, placebo. 



Fig. 2. (a-f) Total symptom, nasal congestion on waking and daily, rhinorrhea, sneezing and nasal itching scores, respectively. Data are reported as mean ( $95 \%$ confidence interval, $\mathrm{Cl}$ ) of the mean of individual score during the treatment period. The comparison between the treatments are reported in Table 2.

\section{Nasal lavage}

Eosinophils Figure 3 shows the mean difference (95\% CI) of nasal percentage of eosinophils at the end of the season minus the nasal percentage of eosinophils before the season. All treatments showed significant differences $(P<0.001)$ compared with PLA. There were no significant differences between the group treated with FPANS and the group treated with FPANS plus CTZ and the group treated with FPANS plus MSK. Besides, there were significant differences $(P<$ $0.001)$ between the groups treated with FPANS alone or in combined therapy and the group treated with CTZ plus MSK.

ECP The mean difference $(95 \% \mathrm{CI})$ of nasal ECP at the end of the season minus the nasal ECP before the season is reported in Fig. 4. All treatments showed significant differences $(P<0.001)$ compared with PLA. There were no significant difference between the group treated with FPANS and the group treated with FPANS plus CTZ and the group treated with FPANS plus MSK. There were significant differences $(P<0.001)$, instead, between the groups treated with FPANS alone or in combined therapy and the group treated with CTZ plus MSK.

\section{Safety}

A low incidence of adverse events was observed in the study. All adverse events were rated as mild. Respiratory symptoms were reported by seven patients in PLA group. Exacerbation 
Table 2. Mean values for FPANS, FPANS plus CTZ, FPANS plus MSK, CTZ plus MSK and PLA (95\% Cl for mean) and mean differences between the treatments for total symptom score (out of 12) nasal blockage on waking (out of 3 ) and daily (out of 3 ), rhinorrhea (out of 3 ), sneezing (out of 3 ) and nasal itching (out of 3)

\begin{tabular}{|c|c|c|c|c|c|c|}
\hline \multirow[b]{2}{*}{ Treatments } & \multicolumn{6}{|c|}{$\begin{array}{l}\text { Subjective symptoms of rhinitis } \\
\text { Mean }(95 \% \mathrm{Cl})\end{array}$} \\
\hline & TSS & $\begin{array}{l}\text { Nasal congestion } \\
\text { on waking }\end{array}$ & $\begin{array}{l}\text { Nasal congestion } \\
\text { daily }\end{array}$ & Rhinorrhea & Sneezing & Nasal itching \\
\hline FPANS & $3.0(2.8-3.1)$ & $0.8(0.7-0.9)$ & $0.9(0.8-0.9)$ & $0.5(0.5-0.6)$ & $0.9(0.8-0.9)$ & $0.6(0.5-0.7)$ \\
\hline FPANS plus CTZ & $2.8(2.6-2.9)$ & $0.7(0.7-0.8)$ & $0.8(0.8-0.9)$ & $0.6(0.5-0.6)$ & $0.8(0.7-0.8)$ & $0.5(0.4-0.5)$ \\
\hline FPANS plus MSK & $3.0(2.8-3.1)$ & $0.7(0.7-0.8)$ & $0.8(0.8-0.9)$ & $0.6(0.5-0.6)$ & $0.8(0.8-0.9)$ & $0.6(0.6-0.7)$ \\
\hline CTZ plus MSK & $3.3(3.1-3.5)$ & $1.2(1.2-1.3)$ & $1.2(1.2-1.3)$ & $0.5(0.5-0.6)$ & $0.8(0.7-0.9)$ & $0.6(0.6-0.7)$ \\
\hline PLA & $4.7(4.5-4.9)$ & $1.3(1.2-1.3)$ & $1.2(1.1-1.3)$ & $1.3(1.2-1.3)$ & $1.1(1.1-1.2)$ & $0.9(0.8-0.9)$ \\
\hline & \multicolumn{6}{|l|}{ Comparisons } \\
\hline Differences FPANS vs. PLA & $\begin{array}{l}-1.6 \\
(-1.8 \text { to }-1.4) \\
P<0.001\end{array}$ & $\begin{array}{l}-0.5 \\
(-0.5 \text { to }-0.4) \\
P<0.001\end{array}$ & $\begin{array}{l}-0.3 \\
(-0.4 \text { to }-0.3) \\
P<0.001\end{array}$ & $\begin{array}{l}-0.7 \\
(-0.7 \text { to } 0.6) \\
P<0.001\end{array}$ & $\begin{array}{l}-0.3 \\
(-0.3 \text { to }-0.2) \\
P<0.001\end{array}$ & $\begin{array}{l}-0.2 \\
(-0.3 \text { to }-0.1) \\
P<0.001\end{array}$ \\
\hline Differences FPANS vs. FPANS plus CTZ & $\begin{array}{l}0.2 \\
(0.08 \text { to }-0.4) \\
P=0.04\end{array}$ & $\begin{array}{l}0.06 \\
(-0.01 \text { to } 0.1) \\
P=\mathrm{NS}\end{array}$ & $\begin{array}{l}0.04 \\
(-0.03 \text { to } 0.1) \\
P=\mathrm{NS}\end{array}$ & $\begin{array}{l}-0.04 \\
(-0.88 \text { to } 0.006) \\
P=\mathrm{NS}\end{array}$ & $\begin{array}{l}0.08 \\
(-0.008 \text { to } 0.1) \\
P=\text { NS }\end{array}$ & $\begin{array}{l}0.1 \\
(0.06 \text { to } 0.2) \\
P=0.003\end{array}$ \\
\hline Differences FPANS vs. FPANS plus MSK & $\begin{array}{l}0.02 \\
(-0.1 \text { to } 0.2) \\
P=\mathrm{NS}\end{array}$ & $\begin{array}{l}0.05 \\
(-0.02 \text { to } 0.1) \\
P=\mathrm{NS}\end{array}$ & $\begin{array}{l}0.04 \\
(-0.03 \text { to } 0.1) \\
P=\mathrm{NS}\end{array}$ & $\begin{array}{l}-0.02 \\
(-0.06 \text { to } 0.02) \\
P=\text { NS }\end{array}$ & $\begin{array}{l}0.02 \\
(-0.04 \text { to } 0.1) \\
P=\mathrm{NS}\end{array}$ & $\begin{array}{l}-0.02 \\
(-0.09 \text { to } 0.05) \\
P=\text { NS }\end{array}$ \\
\hline Differences FPANS vs. FPANS plus MSK & $\begin{array}{l}0.02 \\
(-0.1 \text { to } 0.2) \\
P=\mathrm{NS}\end{array}$ & $\begin{array}{l}0.02 \\
(-0.1 \text { to } 0.2) \\
P=\mathrm{NS}\end{array}$ & $\begin{array}{l}0.02 \\
(-0.1 \text { to } 0.2) \\
P=\mathrm{NS}\end{array}$ & $\begin{array}{l}0.02 \\
(-0.1 \text { to } 0.2) \\
P=\mathrm{NS}\end{array}$ & $\begin{array}{l}0.02 \\
(-0.1 \text { to } 0.2)\end{array}$ & $\begin{array}{l}0.02 \\
(-0.1 \text { to } 0.2) \\
P=\mathrm{NS}\end{array}$ \\
\hline Difference FPANS vs. CTZ plus MSK & $\begin{array}{l}-0.3 \\
(-0.5 \text { to }-0.07) \\
P=0.009\end{array}$ & $\begin{array}{l}-0.4 \\
(-0.5 \text { to }-0.3) \\
P<0.001\end{array}$ & $\begin{array}{l}-0.3 \\
(-0.4 \text { to }-0.2) \\
P<0.001\end{array}$ & $\begin{array}{l}0.02 \\
(-0.01 \text { to } 0.07) \\
P=\text { NS }\end{array}$ & $\begin{array}{l}0.04 \\
(-0.03 \text { to } 0.1) \\
P=\text { NS }\end{array}$ & $\begin{array}{l}0.002 \\
(-0.07 \text { to } 0.07) \\
P=\mathrm{NS}\end{array}$ \\
\hline Diffrences FPANS plus CTZ vs. PLA & $\begin{array}{l}-1.8 \\
(-2.1 \text { to } 11.6) \\
P<0.001\end{array}$ & $\begin{array}{l}-0.5 \\
(-0.6 \text { to }-0.4) \\
P<0.001\end{array}$ & $\begin{array}{l}-0.4 \\
(-0.4 \text { to }-0.3) \\
P<0.001\end{array}$ & $\begin{array}{l}-0.6 \\
(-0.7 \text { to } 0.6) \\
P<0.001\end{array}$ & $\begin{array}{l}-0.3 \\
(-0.4 \text { to }-0.3) \\
P<0.001\end{array}$ & $\begin{array}{l}-0.4 \\
(-0.4 \text { to }-0.3) \\
P<0.001\end{array}$ \\
\hline Difference FPANS plus CTZ vs. FPANS plus MSK & $\begin{array}{l}-0.1 \\
(-0.4 \text { to } 0.01) \\
P=\text { NS }\end{array}$ & $\begin{array}{l}-0.005 \\
(-0.08 \text { to } 0.06) \\
P=\mathrm{NS}\end{array}$ & $\begin{array}{l}-0.0001 \\
(-0.07 \text { to } 0.07) \\
P=\text { NS }\end{array}$ & $\begin{array}{l}0.01 \\
(-0.02 \text { to } 0.06) \\
P=\text { NS }\end{array}$ & $\begin{array}{l}-0.05 \\
(-0.1 \text { to } 0.01) \\
P=\text { NS }\end{array}$ & $\begin{array}{l}-0.1 \\
(-0.2 \text { to }-0.08) \\
P<0.001\end{array}$ \\
\hline Difference FPANS plus CTZ vs. CTZ plus MSK & $\begin{array}{l}-0.5 \\
(-0.7 \text { to }-0.2) \\
P<0.001\end{array}$ & $\begin{array}{l}-0.5 \\
(-0.6 \text { to }-0.4) \\
P<0.001\end{array}$ & $\begin{array}{l}-0.4 \\
(-0.4 \text { to }-0.3) \\
P<0.001\end{array}$ & $\begin{array}{l}0.07 \\
(0.02 \text { to } 0.1) \\
P=0.04\end{array}$ & $\begin{array}{l}-0.04 \\
(-0.1 \text { to } 0.03) \\
P=\text { NS }\end{array}$ & $\begin{array}{l}-0.1 \\
(-0.2 \text { to }-0.06) \\
P=0.003\end{array}$ \\
\hline Difference FPANS plus MSK vs. PLA & $\begin{array}{l}-1.6 \\
(-1.9 \text { to }-1.4) \\
P<0.001\end{array}$ & $\begin{array}{l}-0.5 \\
(-0.6 \text { to }-0.4) \\
P<0.001\end{array}$ & $\begin{array}{l}-0.4 \\
(-0.5 \text { to }-0.3) \\
P<0.001\end{array}$ & $\begin{array}{l}-0.7 \\
(0.7 \text { to }-0.6) \\
P<0.001\end{array}$ & $\begin{array}{l}-0.3 \\
(-0.3 \text { to }-0.2) \\
P<0.001\end{array}$ & $\begin{array}{l}-0.2 \\
(-0.3 \text { to }-0.1) \\
P<0.001\end{array}$ \\
\hline Difference FPANS plus MSK vs. CTZ plus MSK & $\begin{array}{l}-0.3 \\
(-0.5 \text { to }-0.09) \\
P=0.005\end{array}$ & $\begin{array}{l}-0.5 \\
(-0.7 \text { to }-0.2) \\
P<0.001\end{array}$ & $\begin{array}{l}-0.3 \\
(-0.5 \text { to }-0.4) \\
P<0.001\end{array}$ & $\begin{array}{l}0.05 \\
(0.003 \text { to } 0.09) \\
P=\mathrm{NS}\end{array}$ & $\begin{array}{l}0.01 \\
(-0.06 \text { to } 0.08) \\
P=\mathrm{NS}\end{array}$ & $\begin{array}{l}0.02 \\
(-0.05 \text { to } 0.09) \\
P=\text { NS }\end{array}$ \\
\hline Difference CTZ plus MSK vs. PLA & $\begin{array}{l}-1.3 \\
(-1.5 \text { to }-1.1) \\
P<0.001\end{array}$ & $\begin{array}{l}-0.03 \\
(-0.1 \text { to } 0.04) \\
P=\text { NS }\end{array}$ & $\begin{array}{l}-0.02 \\
(-0.09 \text { to } 0.04) \\
P=\mathrm{NS}\end{array}$ & $\begin{array}{l}-0.7 \\
(0.8 \text { to }-0.7) \\
P<0.001\end{array}$ & $\begin{array}{l}-0.3 \\
(-0.4 \text { to }-0.2) \\
P<0.001\end{array}$ & $\begin{array}{l}-0.2 \\
(-0.3 \text { to }-0.1) \\
P<0.001\end{array}$ \\
\hline
\end{tabular}

CTZ, cetirizine; MSK, montelukast; PLA, placebo; TSS, total symptom score; $\mathrm{Cl}$, confidence interval; NS, not significant.

Table 3. Mean blood eosinophil counts $( \pm \mathrm{SD}) \times 10^{-3} \mu \mathrm{L}$ obtained in five treatment groups

\begin{tabular}{llll}
\hline & $\begin{array}{l}\text { FPANS group } \\
(n=20)\end{array}$ & $\begin{array}{l}\text { FPANS plus CTZ group } \\
(n=20)\end{array}$ & $\begin{array}{l}\text { FPANS plus MSK group } \\
(n=20)\end{array} \quad \begin{array}{l}\text { CTZ plus MSK group } \\
(n=20)\end{array}$ \\
\hline Before beginning of season & $0.196 \pm 0.025$ & $0.195 \pm 0.027$ & $0.194 \pm 0.024$ \\
During season & $0.198 \pm 0.020^{*}$ & $0.196 \pm 0.026^{*}$ & $0.196 \pm 0.023^{*}$ \\
At the end of the season & $0.185 \pm 0.023 \dagger$ & $0.195 \pm 0.026 \dagger$ & $0.195 \pm 0.024$ \\
\hline
\end{tabular}

FPANS, fluticasone propionate aqueous nasal spray; CTZ, cetirizine; MSK, montelukast; PLA, placebo.

${ }^{\star} P<0.0003$ compared with placebo. ${ }^{\dagger} P<0.0001$ compared with placebo. 


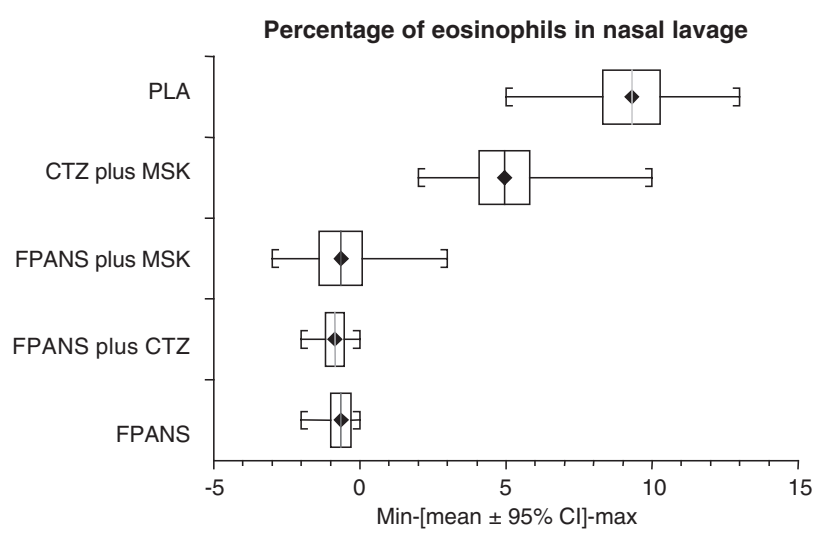

Fig. 3. Data are presented as mean (95\% confidence interval, $\mathrm{Cl}$ ) of percentage of eosinophils in nasal lavage using the values at the end of the season minus the values before the season. $P<0.001$ comparing active treatments vs. placebo and FPANS alone or in combined therapy vs. cetirizine (CTZ) plus montelukast (MSK). No significant difference was observed between FPANS in mono-therapy and in combined therapy.

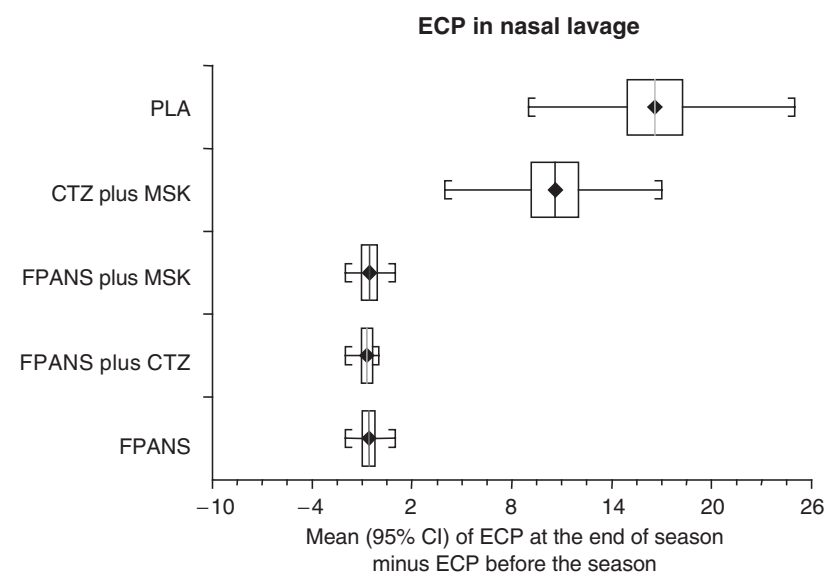

Fig. 4. Eosinophil cationic protein (ECP) in nasal lavage. Data are presented as mean ( $95 \%$ confidence interval, $\mathrm{Cl}$ ) of ECP in nasal lavage using the values at the end of the season minus the values before the season. $P<0.001$ comparing active treatments vs. placebo and FPANS alone or in combined therapy vs. cetirizine (CTZ) plus montelukast (MSK). No significant difference was observed between FPANS in mono-therapy and in combined therapy.

of nasal symptoms after treatment (follow-up period) was reported only in one patient in the PLA group.

\section{Discussion}

The inflammatory cell changes are evident in relationship to clinical disease expression, and the symptoms of rhinitis, that is, nasal itching, sneezing, rhinorrhoea, nasal congestion and loss of sense of smell, may be explained on the basis of mediator release from inflammatory cells [12, 15-19]. However, end organ receptor antagonist, as anti- $\mathrm{H}_{1}[12,20]$ and antileukotriene administered in mono-therapy, does not give a control of symptoms [13,21,22]. The nose is a small organ comprising less than $1 \%$ of total body mass and surface area, and it is therefore logical to confine treatment of rhinitis to the diseased organ with topical drugs $[15,23]$.
The results of this comparative study demonstrate that fluticasone propionate regularly administered once daily is more effective for the treatment of nasal symptoms in patients with allergic rhinitis than CTZ plus MSK given once day orally. As regards nasal symptoms improving, the combination of FPANS with CTZ or with MSK failed to produce a substantial advantage with respect to FPANS administered in mono-therapy. In addition, FPANS treatment, both in mono-therapy and in combined therapy, prevents eosinophil increase in the nose during pollen season as measured in nasal lavage, whereas the use of mediator antagonists in combined therapy, failed to produce this effect. The same results were obtained by analysing ECP levels in nasal lavage of the different groups. In fact, ECP values in the nasal lavages were unchanged only in the groups treated with FPANS, whereas significant increases, during pollen season, were observed in the groups treated with CTZ plus MSK and PLA.

Our study confirms that topical treatment with glucocorticosteroid reduces obstruction on waking and during the day, rhinorrhea, sneezing and itching and that its clinical efficacy on the first two symptoms was greater than that produced by antireceptor antagonists [12, 20-22, 24-26]. It is noteworthy that patients who received FPANS, in mono-therapy or in combined therapy, were free from nasal congestion in approximately $40 \%$ of the scheduled period, without significant difference with respect to the groups treated with combination therapy (i.e. FPANS plus CTZ and FPANS plus MSK). These results suggest that this effect is due to the topical corticosteroid. In addition to the control of the allergic nasal symptoms FPANS, in mono-therapy appears to be not different from FPANS in combined therapy for the use of rescue medication. On the contrary, the use of rescue medication was higher in the subjects treated with antireceptors antagonist in combined therapy. However, it should be noted that most patients included in the PLA group refrained from taking levocabastine nasal spray. This phenomenon has been previously noted in other clinical studies [20].

The effectiveness of topical corticosteroids, as FPANS, for the management of allergic rhinitis is most likely related to multiple pharmacological actions of these drugs on inflammatory cells and on nasal mucosa cells. Besides, topical corticosteroids have proven efficacy in the treatment of allergic rhinitis and their regular administration has been shown to inhibit both the immediate and late response to allergen provocation [23]. They inhibit the transcription of several cytokines and adhesion molecules that are relevant in rhinitis, including IL-5, IL-13, eotaxin and intercellular adhesion molecule-1, involved in the migration of eosinophils in the nasal mucosa and in their activity [12, 27-29]. A large number of clinical studies have shown equal efficacy of topical corticosteroids on all three major symptoms of allergic rhinitis, that is, sneezing, watery rhinorrhea and nasal obstruction, in contrast to antihistamine treatment, which has little effect on nasal obstruction [1, 2]. In fact, topical steroids, but not $\mathrm{H}_{1}$-antihistamines and leukotriene antagonists, in mono-therapy, control the eosinophils influx, responsible for persistent nasal symptoms [21, 22].

On the other hand, MSK mono-therapy has demonstrated clinical benefits in asthma, because it reduced allergeninduced early- and late-phase bronchoconstriction [30]. These data support the hypothesis that leukotrienes are more 
important mediators in the lower respiratory airways. More pronounced effects on symptoms of the lower airways (i.e. bronchostruction) of leukotrienes antagonist may argue that lower and upper airways respond differently to leukotrienes. That may explain the modest beneficial effect of a leukotriene receptor antagonist in our study. On the other hand, it has been shown that nasal challenge with exogenous leukotrienes causes nasal congestion, with very limited effects on itching, sneezing or rhinorrhea [31-33]. One study suggested that 4 weeks of treatment with pranlukast, a leukotriene receptor antagonist, improved symptoms by only $24 \%$ compared with PLA on week 4 of treatment [34].

In conclusion, FPANS intranasal is highly effective for treating patients affected by allergic rhinitis, with efficacy exceeding that of antihistamines and antileukotrienes in combined therapy. The regular combined therapy of FPANS with antihistamines or antileukotrienes does not seem to offer substantial advantage with respect to FPANS in monotherapy, in patients affected by seasonal allergic rhinitis, according to other authors [35]. On the other hand, the daily cost of anti $\mathrm{H}_{1}$ receptor treatment is $0.53 €$, whereas the daily cost of a nasal steroid treatment is $0.63 €$ and the daily cost of antileukotriene receptor treatment is $2.02 €$. Therefore, we think that the combined therapy CTZ and MSK economically is not proposable as regards the treatment of seasonal allergic rhinitis, either mild or moderate. Finally, the upper efficacy of continuous use of intranasal corticosteroids would reduce health care costs.

\section{Acknowledgements}

This study was supported by grants from Ministero Italiano Università e Ricerca (MIUR) (fondi ex60\%) to Gabriele Di Lorenzo, Maria Luisa Pacor and Calogero Caruso and received no support from the pharmaceutical industry. Statistical advice was kindly provided by Full Professor Antonio Motisi (Dipartimento di Coltivazioni Arboree, University of Palermo).

\section{References}

1 Bousquet $\mathrm{J}$, van Cauwenberge $\mathrm{P}$, Khaltaev $\mathrm{N}$ et al. Allergic rhinitis and its impact on asthma. Workshop report in collaboration with the World Health Organisation 2001. J Allergy Clin Immunol 2001; 108 (Suppl. 5):S147-334.

2 van Cauwenberge P, Bachert C, Passalacqua $\mathrm{G}$ et al. Consensus statement on the treatment of allergic rhinitis. Allergy 2000; 55:116-34.

3 Weiner JM, Abramson MJ, Puy RM. Intranasal corticosteroids vs. oral $\mathrm{H}_{1}$ receptor antagonists in allergic rhinitis. systematic review of randomised controlled trials. Br Med J 1998; 317:1624-9.

4 Smith LJ. Comparative efficacy of inhaled corticosteroids and antileukotriene drugs in asthma. Biodrugs 2001; 15:239-49.

5 Sorkness CA. Leukotriene receptor antagonists in the treatment of asthma. Pharmacotherapy 2001; 21:S34-7.

6 Ducharme FM, Hicks GC. Anti-leukotriene agents compared to inhaled corticosteroids in the management of recurrent and/or chronic asthma. Cochrane Database Syst Rev 2000; 3:CD002314.

7 Meltzer EO, Malmstrom K, Lu S et al. Concomitant montelukast and loratadine as treatment for seasonal allergic rhinitis: a randomized, placebo-controlled clinical trial. J Allergy Clin Immunol 2000; 105:917-22.

8 Wilson AM, Orr LC, Sims EJ, Lipworth BJ. Effects of monotherapy with intra-nasal corticosteroid or combined oral histamine and leukotriene receptor antagonists in seasonal allergic rhinitis. Clin Exp Allergy 2001; 31:61-8.

9 Wilson AM, Sims EJ, Orr LC et al. Effects of topical corticosteroid and combined mediator blockade on domiciliary and laboratory measurements of nasal function in seasonal allergic rhinitis. Ann Allergy Asthma Immunol 2001; 87:344-9.

10 Di Lorenzo G, Mansueto P, Melluso M et al. Non specific airway hyperresponsiveness in mono-sensitive Sicilian patients with allergic rhinitis. Its relation to total serum IgE levels and blood eosinophils during and out of the pollen season. Clin Exp Allergy 1997; 27:1052-9.

11 Dacie JV, Lewis SM. Eosinophil counts by counting chamber method. In: Lewis SM, Bain BJ, Bates I, eds. Practical Haematology. Edinburgh: Churchill Livingstone, 1984: 42-3.

12 Di Lorenzo G, Gervasi F, Drago A et al. Comparison of the effects of fluticasone propionate, aqueous nasal spray and levocabastine on inflammatory cells in nasal lavage and clinical activity during the pollen season in seasonal rhinitics. Clin Exp Allergy 1999; 29:1367-77.

13 Di Lorenzo G, Drago A, Esposito Pelliteri M et al. Measurement of inflammatory mediators of mast cell and eosinophils in native nasal fluid lavage in nasal polyposis. Int Arch Allergy Immunol 2001; 25:164-75.

14 Erdfelder E, Faul F, Buchner A. GPower: a general power analysis program. Behav Res Meth, Instr Comput 1996; 28:1-11.

15 Howarth PH. The cellular basis for allergic rhinitis. Allergy 1995; 50:6-10.

16 Di Lorenzo G, Mansueto P, Melluso M et al. Allergic rhinitis to Grass pollen: measurement of inflammatory mediators of mast cell and eosinophils in native nasal fluid lavage and in serum out and during pollen season. J Allergy Clin Immunol 1997; 100:832-7.

17 Mygind N, Dahl R. The rationale use of topical corticosteroids in allergic rhinitis. Clin Exp Allergy 1996; 26 (Suppl. 3):2-10.

18 Dujukanovic R, Wilson SJ, Howarth H. Pathology of rhinitis and bronchial asthma. Clin Exp Allergy 1996; 26 (Suppl. 3):44-51.

19 Palczynsky C, Krakowiak A, Ruta U et al. Nasal response to allergen challenge in patients with immediate asthmatic reaction. Allergol Immunopathol (Madr) 1996; 24:237-42.

20 Ortolani C, Foresi Athe FLNC02 Italian Study Group et al. A double-blind, placebo-controlled comparison of treatment with fluticasone propionate and levocabastine in patients with seasonal allergic rhinitis. Allergy 1999; 54:1173-80.

21 Pullerits T, Praks L, Skoogh BE, Ani R, Lotvall J. Randomized placebo-controlled study comparing a leukotriene receptor antagonist and a nasal glucocorticoid in seasonal allergic rhinitis. Am J Respir Crit Care Med 1999; 159:1814-8.

22 Pullerits T, Praks L, Ristioja V, Ltvall J. Comparison of a nasal glucocorticoid, antileukotriene, and a combination of antileukotriene and antihistamine in the treatment of seasonal allergic rhinitis. J Allergy Clin Immunol 2002; 109:949-55.

23 Godthelp T, Holm AF, Klein-Jan A, Rijntjes E, Fokkens WJ. The effect of fluticasone propionate aqueous nasal spray on nasal mucosal inflammatory in perennial allergic rhinitis. Allergy 1995; 50:21-4.

24 D'Ambrosio FP, Gangemi S, Merendino RA, Arena A, Ricciardi L, Bagnato GF. Comparative study between fluticasone propionate and cetirizine in the treatment of allergic rhinitis. Allergol Immunopathol (Madr) 1998; 26:277-82.

25 Jordana G, Dolovich J, Briscoe MP et al. Intranasal fluticasone propionate vs. loratadine in the treatment of adolescent patients with seasonal allergic rhinitis. J Allergy Clin Immunol 1996; 97:588-95. 
26 Darnell R, Pecoud A, Richards DH. A double-blind comparison of fluticasone propionate aqueous nasal spray, terfenadine tablets and placebo in the treatment of patients with seasonal allergic rhinitis to grass pollen. Clin Exp Allergy 1994; 24:1144-50.

27 Barnes PJ. Molecular mechanisms of corticosteroids in allergic diseases. Allergy 2001; 56:928-36.

28 Barnes PJ, Pedersen S, Busse WW. Efficacy and safety of inhaled corticosteroids. New developments. Am J Respir Crit Care Med 1998; 157:S1-53.

29 Di Lorenzo G, Pacor ML, Esposito-Pellitteri M et al. In vitro effects of fluticasone propionate on interleukin-13 production by mitogen-stimulated. Mediat Inflamm 2002; 11:187-90.

30 Diamant Z, Grootendorst DC, Veselic-Charvat $\mathrm{M}$ et al. The effect of montelukast (MK-0476), a cysteinyl leukotriene receptor antagonist, on allergen-induced airway responses and sputum cell counts in asthma. Clin Exp Allergy 1999; 29:42-51.
31 Miadonna A, Tedeschi A, Leggieri E et al. Behavior and clinical relevance of histamine and leukotrienes C4 and B4 in grass pollen-induced rhinitis. Am Rev Respir Dis 1987; 136:357-62.

32 Bisgaard $\mathrm{H}$, Olsson $\mathrm{P}$, Bende $\mathrm{M}$. Effect of leukotriene $\mathrm{D}_{4}$ on nasal mucosal blood flow, nasal airway resistance and nasal secretion in humans. Clin Allergy 1986; 60:289-97.

33 Okuda M, Watase T, Mezawa A, Liu CM. The role of leukotriene $\mathrm{D}_{4}$ in allergic rhinitis. Ann Allergy 1988; 60:537-40.

34 Grossman J, Ratner PH, Nathan R, Adelglass J, de Jong B. Pranlukast (Ultair ${ }^{\mathrm{TM}}$, SB 205312, ONO-1078), an oral leukotriene receptor antagonist, relieves symptoms in patients with seasonal allergic rhinitis (SAR) (abstract). J Allergy Clin Immunol 1997; 99:S443.

35 Nielsen LP, Mygind N, Dahl R. Intranasal corticosteroids for allergic rhinitis: superior relief? Drugs 2001; 61:1563-79. 